\title{
CUTTING RED TAPE - LEgAL AND INSTITUTIONAL TOOLS TO PROMOTE SMES
}

\author{
Tina Sever ${ }^{1}$, Dejan Ravšelj ${ }^{2}$, Aleksander Aristovnik ${ }^{3}$, Polonca Kovač $^{4}$
}

\begin{abstract}
The pursuit of global competitiveness requires a complex system of measures that enable the promotion of business. Yet this goal is strongly hindered by interdisciplinary (legal, economic, managerial, IT) red tape programs in both national and supranational frameworks. The aim of the paper is to enhance the understanding of red tape by identifying key sector-specific problems in administrative areas that are crucial for SMEs and offer suggestions for improvement. The paper explores measures related to red tape in the Slovenian and European contexts based on the understanding that transparent regulation with efficient procedures is a precondition for a business-friendly environment that attracts investments. The research is based on a combination of empirical methods applied to a base of over 900 surveys collected from Slovenian SMEs in 2016 and 2017. The results show that entrepreneurs see the greatest administrative burdens in the area of accounting and financial reports, especially the number of the documents needed, the time needed to perform a procedure, and the need for outsourcing.
\end{abstract}

Keywords

Red Tape Reduction, Administrative Burden, Doing Business, SMEs, Stakeholders' Perception, Slovenia

\section{Introduction}

Small and medium sized enterprises (hereinafter SMEs) account for $99.82 \%$ of all Slovenian enterprises and generate altogether $66.76 \%$ of the total turnover. As such, they are an important driving force in economy. Therefore, providing a business-friendly environment for SMEs should be one of the state's main goals.

The paper aims to analyse SMEs as stakeholders and their perspective on policymaking, law-making, organization, and law enforcement in terms of red tape reduction.

\footnotetext{
${ }^{1}$ University of Ljubljana, Gosarjeva ulica 5, 1000 Ljubljana, Slovenia. E-mail: tina.sever@fu.uni-lj.si.

${ }^{2}$ University of Ljubljana, Gosarjeva ulica 5, 1000 Ljubljana, Slovenia. E-mail: dejan.ravselj@fu.uni-lj.si.

${ }^{3}$ University of Ljubljana, Gosarjeva ulica 5, 1000 Ljubljana, Slovenia. E-mail: aleksander.aristovnik @ fu.uni-lj.si.

${ }^{4}$ University of Ljubljana, Gosarjeva ulica 5, 1000 Ljubljana, Slovenia. E-mail: polonca.kovac@ fu.uni-lj.si.
} 
In this respect, the paper focuses on the G2B relationship. The state should strive to create a business environment that imposes administrative burdens by law only when needed to protect the public interest, preserve order and enable legal certainty. Rules that could be removed without detriment to the public interest are administrative barriers, which should be identified preferably already in the law-making phase and removed.

The aim of the paper is to enhance the understanding of red tape by identifying key sectorspecific problems in administrative areas that are crucial for SMEs and offer suggestions for improvement.

To perform our research, we firstly needed to identify crucial administrative areas that are relevant for SMEs. For such purpose, we took as a basis the criteria defined by the World Bank Doing Business research project. By analysing such, we identified seven crucial administrative areas important for SMEs when dealing with the state where they might encounter administrative barriers. These are sectoral regulation, functioning of the job market, ease of paying public duties, reporting to the state, efficiency of the performance of inspection, acquiring construction permits, and (re)establishing an enterprise.

Secondly, we needed to identify the most common administrative barriers hindering successful business making. In order to do so, we gathered data from professional forums in public and through representatives of the Chamber of Commerce and Industry of Slovenia and the Chamber of Crafts and Small Business of Slovenia, which pointed out the following administrative barriers: extra time, extra financial resources, outsourcing, frequent legislation amendments, too many procedures, extra needed communication and extent of documents. Based on the theoretical framework and gathered data, a questionnaire for SMEs was formulated. The aim was to obtain the SMEs' perspective on understanding the terms administrative burdens and administrative barriers and to identify the most "problematic" administrative areas with the most frequent administrative barriers for them. Finally, we proposed possible solutions to improve the current state of affairs and were interested in their evaluation.

The research was a multi-year research, initiated in 2016. The first stage was intended to examine the relevant theoretical background. It was followed by formulating a questionnaire to be given to SMEs. Altogether, this stage took approximately 10 months. The following 6 months were dedicated to data collecting via internet and in the field. Finally, the last 8 months were dedicated to data analysing and paper writing.

Below, the structure of the paper is as follows: first, a literature review of red tape and related terms is given. It is followed by defining the research questions and the relevant methodology applied during the research (the sample, collection and analysis of data). The fourth chapter presents the results and is followed by their discussion and conclusion with the relevant recommendations for future improvements.

\section{Red tape reduction in theory}

The global economy is opening new opportunities yet putting additional challenges on players in the market. Therefore, the role of the state - as the main regulator and public policymaker - and business, particularly the majority of small and medium sized enterprises, need to adapt to the new relationships if competiveness is to be achieved. 
Moreover, red tape is recognized as a factor of economic growth and cross-border competiveness, in taxation, the social field, trade and investments etc. (Braunerhjelm and Eklund, 2014). This is further established based on some recent studies examining the implications of administrative barriers for SMEs in different administrative areas, including taxation (Ravšelj and Aristovnik, 2020; Ravšelj et al., 2019) and employment (Obadić et al., 2020).

In Slovenia, SMEs account for almost the whole population of enterprises, providing over $72 \%$ of employment and nearly $63 \%$ of value added (European Commission, 2017, pp. 2-3). However, compared with larger enterprises, SMEs operate somewhat less successfully with lower profitability, higher staff turnover, a lower survival rate etc. (Szczepański, 2016, cf. Aristovnik and Obadić, 2015).

In order to find ways for red tape reduction (hereinafter RTR), we must first explain its meaning. Namely, the literature contains different arguments and emphasizes that reflect the various research approaches taken by different disciplines, chiefly economics, law, political science or IT (cf. Figure 1).

Figure 1: Red tape reduction at the intersection of contemporary concepts

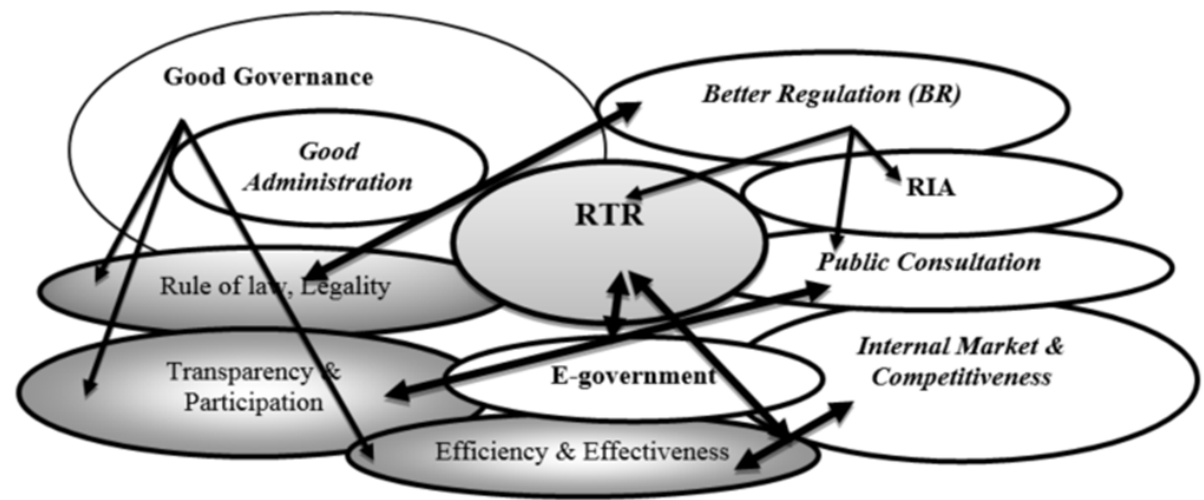

Source: Kovač and Sever (2016)

A literature review shows that red tape has no definite meaning (cf. Pandey and Scott, 2002), but needs to be analysed in a broader perspective that encompasses the concepts of better regulation, good governance, e-government etc. One of the earliest definitions was by Bozeman (1993) when focusing on the organizational perspective, stating that red tape are 'rules, regulations, and procedures that remain in force and entail a compliance burden for the organization but have no efficacy for the rules' functional object'. Over the last few decades, the OECD $(2003,2008)$ and the EU have conducted most of the research, especially promoting better regulation with a focus on the policy (European Commission, 2007; cf. Radaelli and De Francesco, 2007; Cărăuşan, 2016). In addition, some research focus on the outcomes of procedures as perceived by stakeholders (Kaufman and Feeney, 2014; cf. Bozeman, 1993, Rosenfeld, 1984), which is also our research approach. 
The goal of RTR is to cut expenses, save time and increase consumer satisfaction (e.g. entrepreneurs, citizens, legal persons etc.), either preventively in the process of preparing a new regulation or as part of amending a regulation. The core of our research is made up of SMEs as stakeholders and their perspective on policy- and law-making, organization, and law enforcement in terms of RTR (cf. Pandey et al., 2007 on RTR perceptions; Kaufman and Feeney, 2012). We focus on the G2B relationship, i.e. increasing the satisfaction of SMEs and thereby improving the overall business environment. As shown in Figure 1, RTR appears at the intersection of different measures which, when applied holistically, reduce burdens on enterprises.

Over the decades, approaches to RTR have been changing and new ones are emerging. One of the biggest shifts came in the 1980s when the new public management doctrine was introduced, promoting effective use of public funds and ensuring good quality services. In order to achieve good public governance, we need better (smart) regulation. Moreover, smart regulation tools such as impact assessment, stakeholder consultation and evaluation are used in different policy fields (Cărăuşan, 2016; cf. Figure 1). An important phase of assessing the regulatory impact is to measure administrative burdens as part of administrative costs by applying the Standard Cost Model method. Altogether, administrative activities (such as preparation of reports, copying, sending documents etc.), performed by enterprises or individuals only due to regulatory obligation, constitute administrative burdens (International Standard Cost Model Manual, 2005), i.e. the costs and time enterprises and individuals must spend to comply with the law. However, the term administrative burden should be distinguished from the meaning of the narrower term of administrative barrier. Namely, some administrative burdens deriving from the law are needed to protect the public interest, preserve order and enable legal certainty. Yet the remaining rules, which could be removed without detriment to the public interest, are ineffective and produce negative outcomes. These are defined as administrative barriers (Virant and Kovač, 2010; cf. Bozeman, 1993) that should be identified preferably already in the law-making phase and removed.

RTR encourages the optimization of administrative procedures, usually referred to as the simplification of procedures (Virant and Kovač, 2010; cf. OECD, 2003; Donelan, 2008; Kovač, 2018). Simplification is more or less an organizational, managerial measure that is informatization-oriented and aimed at rationalizing a process. This can be achieved by applying principles like "one stop shops"; "single sign on" and "let the data circulate instead of the citizens" (Virant and Kovač, 2010).

Moreover, an important RTR tool is deregulation by reducing the legal conditions before certain rights are acquired (e.g. abolition of the minimum capital need to establish a business, although a permit to enter the market is still needed) or completely transferring certain administrative relations to the free market (i.e. liberalization) (Kovač and Jukić, 2017). Finally, to support all kinds of the above-mentioned RTR approaches we need a good technological basis and therefore the development of e-government, which contributes to overall efficacy of the system (cf. Figure 1). 
One of the biggest research projects in the area of SMEs is Doing Business by the World Bank (cf. Braunerhjelm and Eklund, 2014, pp. 1-11). It analyses the ease of doing business in an individual country based on ten criteria relevant to SMEs (such as starting a business; dealing with construction permits; registering property; paying taxes; enforcing contracts etc.), focusing on the regulatory environment. However, it has attracted some criticism for not always painting an accurate picture, only promoting certain measures to improve the regulatory environment (e.g. deregulation) and enabling only pro forma changes (Đorðević, 2017). Moreover, it does not give an overview of certain other administrative burdens with relevance for SMEs.

In this respect, our research provides an original contribution to understanding red tape by identifying key sector-specific problems for SMEs and by offering suggestions for improvement. We identify seven crucial administrative areas important for SMEs' efficient performance: transparent sectoral regulation, functioning of the job market, the ease of paying public duties, reporting to the state, the efficiency of the performance of inspection, acquiring construction permits and (re)establishing an enterprise.

\section{Research questions and methodology}

The paper deals with the following research questions: a) identifying the vital administrative areas relevant to SMEs in terms of RTR; and b) detecting key RTR measures for SMEs pertinent to these administrative areas.

We studied the following research sub-dimensions: first, setting up a review of theoretical understanding of administrative burdens (see Chapter II.). Second, the actual state of public administration performance according to SMEs' perception in practice. Third, to investigate SMEs' understanding of the administrative burdens, barriers and preferred RTR solution in the future.

Based on red tape reduction theory and literature review, the following research hypotheses were developed. The first hypothesis is that entrepreneurs do not distinguish between the terms administrative burdens and barriers due to the lack of clarity between these two concepts. Moreover, we posit the second hypothesis that, in practice, SMEs perceive the payment of public duties and contributions and construction permit procedures as the most burdensome administrative areas due to the relatively complex nature of administrative procedures. We also put forward the third hypothesis that entrepreneurs perceive as the most suitable solutions regulatory improvements and a higher level of service informatization, since both are focused on the simplification of G2B relationship. Finally, we propose the fourth hypothesis that the suitability of solutions varies depending on the specific administrative area involved since individual specifics require a tailored approach.

In the introduction, a descriptive methodology along with an overview of different standpoints on RTR is provided. In the second part, by applying a normative-analytical method to analyse relevant legislation and to interrelate it with SMEs' 'everyday' performance, seven key administrative areas are identified that are relevant to SMEs when dealing with the state (i.e. public administration) and where they might encounter 
administrative barriers. These key administrative areas are sectoral regulation, functioning of the job market, the ease of paying public duties, reporting to the state, efficiency of the performance of inspection, acquiring construction permits and (re)establishing an enterprise.

First, transparent sectoral regulation is needed to effectively uphold the public interest and the interests of others. Namely, in order to protect public health, the environment, fair trade and other public values, the state regulates various conditions and standards, depending on an enterprise's activity (e.g. pharmacy, agriculture, building sector etc.). In order to be competitive, the entrepreneurs must be informed in advance of the legal conditions to enter a certain market in an individual country, build a factory (e.g. regulation of licenses, hygiene standards etc.). Second, the whole employment process should be performed smoothly, such as the (de)registration of an employee, work safety, managing compulsory insurances (pension and health) etc. Third, the payment of public duties and contributions, as well as communication on financial and accounting reports should be proportionally defined, easily accessible (in e-form where possible) and transparent. On the other hand, in accordance with the public interest, the state should ensure the efficient supervision of enterprises' activities (such as inspections, controls etc.), which adds to the (in)efficiency of the system. Finally, efficient construction permit procedures and establishing or changing the status of an existing enterprise are very important for building a business-friendly environment that can attract new investments. Each of these administrative areas is essentially important for the ways in which SMEs function. The research focuses on SMEs' perception of these areas in practice, i.e. by looking at the regulation, conduct and outcomes of procedures from the entrepreneurs' viewpoint (cf. Kaufman and Feeney, 2014).

In addition, we identified common seven administrative barriers entrepreneurs criticize and mention in different professional forums in public and via representatives of the Chamber of Commerce and Industry of Slovenia as well as the Chamber of Crafts and Small Business of Slovenia. Namely, common to all administrative areas is the perception of entrepreneurs that doing business is hindered by the extra time needed to perform procedures and activities. Beside the time lost, which has financial consequences, they need to spend extra financial resources (e.g. on construction permits) or even outsource certain services (such as accounting, legal services etc.). Moreover, there is a trend of frequent amendments to the legislation that sometimes result in too many different procedures and extra personal communication being required to communicate with administrative bodies and the requirement of too many different documents.

Finally, by applying a systematic approach analysing existing RTR research using the methods of deduction and synthesis, we identify and provide a final list of relevant measures assessed by SMEs in terms of whether they are successful in RTR or not.

In the second part of the paper, theoretical standpoints are supported by empirical data gathered as part of the research among SMEs. Namely, SMEs represent $99.82 \%$ of all Slovenian enterprises and altogether create $66.76 \%$ of the total turnover (Statistical Office RS, 2017). The criteria used to define an enterprise as small or medium-sized are number of employees, annual turnover and annual total assets. These criteria are established similarly 
on the EU level, although annual turnover and annual total assets are set lower in Slovenia (see Table 1) where GDP per capita is EUR 18,693 (Statistical Office RS, 2017).

Table 1: SMEs at the EU and national level

\begin{tabular}{|c|c|c|c|}
\hline Type of enterprise & Number of employees & Annual turnover & Annual balance sheet total \\
\hline $\begin{array}{l}\text { Medium-sized } \\
\text { enterprise }\end{array}$ & $\begin{array}{l}\text { EU: }<250 \\
\text { Slovenia: }<250\end{array}$ & $\begin{array}{l}\text { EU: } \leq € 50 \text { mill. } \\
\text { Slovenia: } \leq € 40 \text { mill. }\end{array}$ & $\begin{array}{l}\text { EU: } \leq € 43 \text { mill. } \\
\text { Slovenia: } \leq € 20 \text { mill. }\end{array}$ \\
\hline $\begin{array}{l}\text { Small-sized } \\
\text { enterprise }\end{array}$ & $\begin{array}{l}\text { EU: }<50 \\
\text { Slovenia: }<50\end{array}$ & $\begin{array}{l}\text { EU: } \leq € 10 \text { mill. } \\
\text { Slovenia: } \leq € 8 \text { mill. }\end{array}$ & $\begin{array}{l}\text { EU: } \leq € 10 \text { mill. } \\
\text { Slovenia: } \leq € 4 \text { mill. }\end{array}$ \\
\hline Micro enterprise & $\begin{array}{l}\text { EU: }<10 \\
\text { Slovenia: }<10\end{array}$ & $\begin{array}{l}\text { EU: } \leq € 2 \text { mill. } \\
\text { Slovenia: } \leq € 0.7 \text { mill. }\end{array}$ & $\begin{array}{l}\text { EU: } \leq € 2 \text { mill. } \\
\text { Slovenia: } \leq € 0.35 \text { mill. }\end{array}$ \\
\hline
\end{tabular}

Source: European Commission (2003); Companies Act (2006 and amendments)

A questionnaire was formulated by academic experts from economic and legal fields and also relied on recommendations made by practitioners, i.e. representatives of the Chamber of Craft and Small Business of Slovenia as well as entrepreneurs. The questionnaire has four different parts, where the first part covers basic information on SMEs. The following parts are more substantive and cover the understanding of administrative barriers, assessment of the current and desired state regarding the enterprise's administrative activities and solutions and measures to remove administrative barriers. It consists of 39 questions altogether, where one was of an open type. The respondents could leave certain parts blank if the content did not apply to them, (e.g. they had not submitted a building permit application in the previous five years etc.). The questionnaire was distributed via two paths, namely through a survey conducted on the Internet and in the field. Since the web survey only resulted in 273 responses, it was accompanied with the field survey. In order to enable the results to be generalized for all Slovenian SMEs, two criteria were applied when selecting the enterprises included in the field survey: regional base and legal status. The field survey produced 652 responses. The whole data collection process lasted from the beginning of November 2016 to the end of April 2017. Altogether, we received 925 questionnaire replies, of which 807 were fully completed.

The majority of the SMEs come from the Central Slovenia Region. This was expected since this region contains the highest density of registered SMEs, those performing the most business, and with the highest income flows. According to the Statistical Office of the RS, 33.02\% of all the country's enterprises are found in this region. Data are for the year 2015 and the sample includes also large enterprises; however, these are in Slovenia only a minority. Therefore, we can conclude, that the SMEs are the prevailing forms. Most SMEs are micro enterprises with fewer than 10 employees $(79.61 \%)$, which is in line with the overall structure of these forms of enterprises in Slovenia (95.26\%). Moreover, most SMEs involved in the research are either limited liability enterprises $(47.46 \%)$ or private entrepreneurs $(47.24 \%)$, which are two of the most common organizational forms of enterprises in Slovenia due to their 'favourable' legal, financial and organizational requirements. The sample is in accordance with the overall structure of these forms of enterprises in Slovenia. Namely, in the overall population of registered enterprises, $30.98 \%$ 
are limited liability enterprises and $54.40 \%$ are private entrepreneurs (Statistical Office of the RS, 2017). For the purposes of the analysis in this paper, the sample is reduced by those SMEs, which have only cooperated with one business partner since their establishment since these are so-called fictitious enterprises. Therefore, the final sample of SMEs used in the analysis includes 817 enterprises, with the sample size varying case by case due to the missing response values.

The data are analysed using different statistical methods. In order to establish which individual administrative areas and administrative barriers among these areas are the most burdensome and which solutions are perceived to be most suitable, descriptive statistics are used. Therefore, the results are presented in the form of shares (percentage) or average values of responses, whereby only valid answers are taken into account for each question. In the latter case, the variables are measured on a five-point scale, where 1 means the lowest value and 5 means the highest value of the variable. In order to establish which solutions for the identified administrative barriers are more suitable for the different administrative areas, Spearman's rank correlation analysis is conducted. Spearman's rank correlation is a non-parametric test that assesses how well an arbitrary monotonic function can describe a relationship between two variables, without making any assumptions about the frequency distribution of the variables. Moreover, Spearman's rank correlation can be used for variables measured on a scale that is at least ordinal (Hauke and Kossowski, 2011). The correlation coefficient can vary from 0 (no relationship) to 1 (perfect positive relationship) or -1 (perfect negative relationship). A positive correlation coefficient indicates that when one variable increases, the other variable also increases. A negative correlation coefficient shows that when one variable increases, the other variable decreases. All variables used in Spearman's rank correlation analysis are measured on a five-point scale, with 1 meaning the lowest value and 5 the highest value of the variable. In order to isolate the effect of SMEs' lack of interest in introducing RTR solutions, only SMEs that believe there are more administrative barriers in Slovenia than abroad are included in the analysis. Therefore, the final sample of SMEs used in the Spearman rank correlation analysis includes 551 enterprises.

\section{Results}

\section{Key sector-specific problems hindering SMEs' business activity}

Our research focused on seven key administrative areas that are important for business, looking up to World Bank list (see Table 2), which similarly recognizes certain key areas for business on the international level.

The results of survey confirm our first hypothesis that entrepreneurs do not distinguish between the terms administrative burden (i.e. necessary rules to protect the public interest) and administrative barrier (unnecessary rules) (Table 3). On the contrary, they understand them as synonyms. Their perception of RTR is more along the lines of 'anything burdensome' across the analysed seven administrative areas that the state requires from them. 
Table 2: Key areas relevant for a business-friendly environment

\begin{tabular}{|l|l|}
\hline \multicolumn{2}{|c|}{ Key (administrative) areas } \\
\hline $\begin{array}{l}\text { Doing Business by the World Bank (research } \\
\text { Focus is on: procedure, time \& cost) }\end{array}$ & $\begin{array}{l}\text { Research performed on SMEs, 2016-2017 } \\
\text { (research focus is on the RTR perception by } \\
\text { SMEs) }\end{array}$ \\
\hline $\begin{array}{l}\text { 1. starting a business; } \\
\text { 2. dealing with construction permits; }\end{array}$ & 1. sectoral regulation; \\
3. getting electricity; & 3. payment of public duties; \\
4. registering property; & 4. accounting; \\
5. getting credit; & 5. inspections; \\
6. protecting minority investors; & 6. construction permits; and \\
7. paying taxes; & 7. (re)establishing an enterprise. \\
8. trading across borders; & \\
9. enforcing contracts; and & \\
10. resolving insolvency. & \\
\hline
\end{tabular}

Source: Doing Business (2016, 2017, 2020); and own (2017)

Table 3: Ranking of key administrative areas

\begin{tabular}{|c|l|c|l|c|}
\hline \multicolumn{2}{|c|}{$\begin{array}{l}\text { Administrative area perceived as an area } \\
\text { loaded with administrative burdens }(\mathrm{N}=689)\end{array}$} & \multicolumn{2}{c|}{$\begin{array}{l}\text { Administrative area perceived as an area } \\
\text { loaded with administrative barriers (N=675) }\end{array}$} \\
\hline Rank & \multicolumn{2}{|c|}{ Area } & Share & \multicolumn{2}{c|}{ Area } & Share \\
\hline 1 & payment of public duties & $53 \%$ & payment of public duties & $45 \%$ \\
\hline 2 & accounting & $46 \%$ & accounting & $38 \%$ \\
\hline 3 & inspections & $27 \%$ & employees & $29 \%$ \\
\hline 4 & employees & $25 \%$ & inspections & $29 \%$ \\
\hline 5 & construction permits & $22 \%$ & construction permits & $20 \%$ \\
\hline 6 & (re)establishing an enterprise & $5 \%$ & (re)establishing an enterprise & $9 \%$ \\
\hline
\end{tabular}

Source: own (2017)

Overall, the average of the responses shows that SMEs find most administrative barriers in the areas of accounting and financial reports, followed by taxes and other contributions, building and similar permits; inspection and control procedures, dealing with the employees ((de)registration; insurances) and finally the (re)establishment of an enterprise (Figure 2). These results are quite understandable since most enterprises need to outsource their accounting services, leading to greater expenses. Moreover, tax system is rather complicated and tax rates in Slovenia are relatively high, which might lead to breaching the law (grey economy) or finding other legal ways (e.g. moving an enterprise to another, more favourable business environment) to avoid it. Finally, the (re)establishment of an enterprise is, as expected, assessed lowly since this is quite a rare event in the 'lifecycle 
of an enterprise'. However, although the entrepreneurs assessed the paying of public duties and construction permits in only second and third place, respectively, these findings support our second hypothesis.

When asked how they would assess these key areas when encountering public administration abroad, all areas were estimated to entail more administrative barriers in Slovenia than, for example, in Austria, Italy or Serbia. Most often, a country with good practices to look up to was Austria (e.g. flexible system of not issuing an official receipt when selling products, flat-rate taxation).

Figure 2: The extent of administrative barriers within individual areas - overview

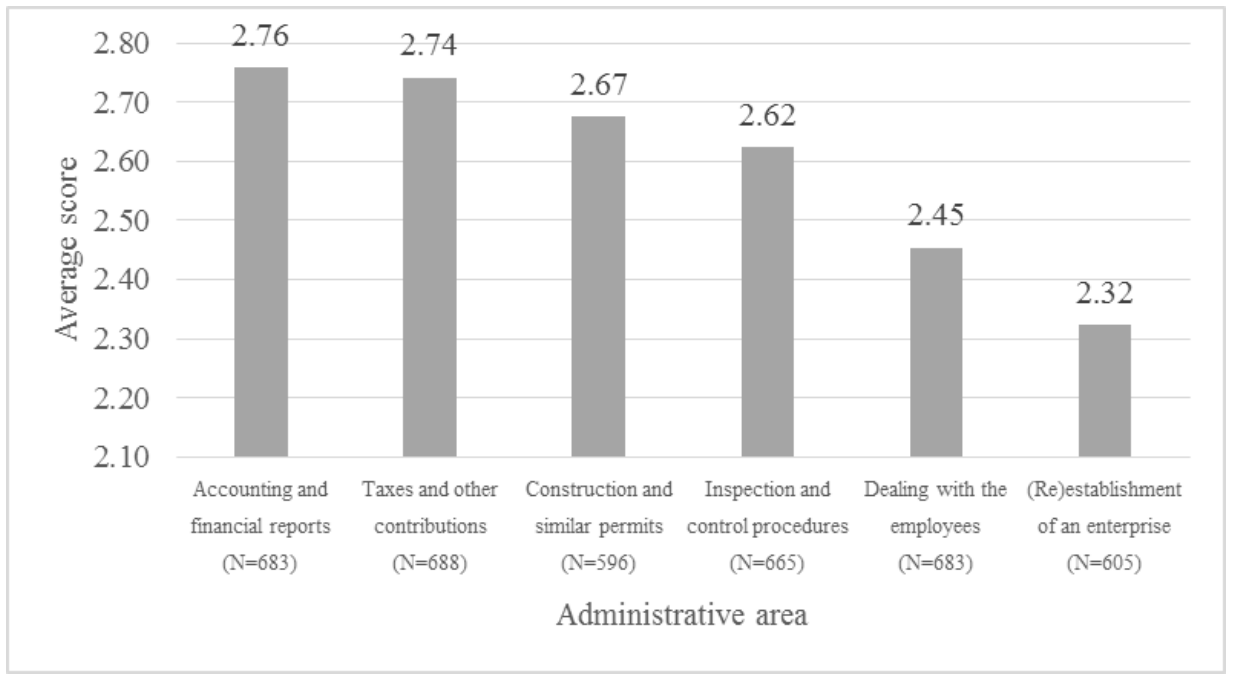

Source: own (2017)

Finally, the analysis examined within each of these individual areas different administrative barriers they might have to deal with in relation to the state (public administration). As shown in Figure 3, as the most business disturbing administrative barriers the respondents identified the requirement of the amount of documents, an extra time needed to perform a procedure, activities, and outsourcing.

The number of documents was identified as the most burdensome in the areas of sectoral regulation, dealing with the employees and when applying for construction (and other similar) permits. This result is quite disappointing given that a considerable share of the data required is available from different registers, which could be interconnected. Moreover, there is a legal requirement that the authorities should exchange registered data by themselves without burdening the applicant.

The burden of time was seen as the most problematic within the inspection (and other control) procedures as well as when (re)establishing an enterprise (Figure 3). The latter is surprising since the statistics suggest it is relatively easy and fast to establish an enterprise in Slovenia (e.g. it takes approximately seven days to set up a limited liability enterprise 
and less than 1 hour to become a private entrepreneur). Moreover, everything can be done online or at the one-stop shops, which also received the United Nations Public Service Award in 2009.

Figure 3: Administrative barriers identified by the SMEs in the selected areas

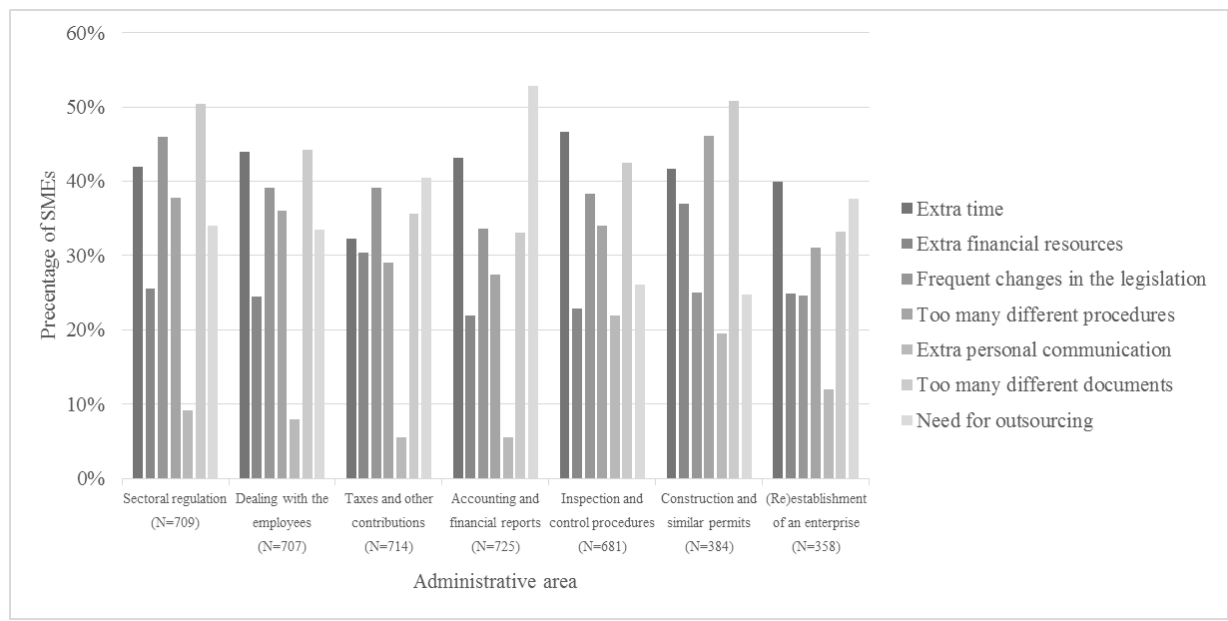

Source: own (2017)

In terms of inspection procedures, it was expected that the time lost is problematic. During these procedures, a fundamental legal principle of proportionality should be applied. As such, these procedures should rarely lead to the closure of an enterprise, except where life, the environment or other public goods need to be preserved. However, just the start of the procedure itself (even if it finishes within a few days) is burdensome for the entrepreneurs (i.e. psychologically, administratively and financially). Extra time needed to perform procedures was identified as the second most problematic within the areas of accounting and financial reports, and when dealing with the employees (Figure 3). However, the extra time entailed could be the result of red tape, but not necessarily (cf. Pandey and Scott, 2002). Namely, certain rules and procedures are required for the system to function.

Finally, the amount of required documents is assessed as burdensome also within the inspection procedures (Figure 3). The reason for this can be found in the extent and content of sectoral legislation, regulating all kinds of relations between the state and enterprises. The aim of such extensive regulation should be to protect the public interest. Yet sometimes the state tries to solve public officials' lack of knowledge etc. by imposing 'hyper' regulation. One example is the regulation of construction permits, which also leads to the problem of too many different procedures (Figure 3). The result of too extensive requirements of sectoral regulation can be 'hyper' documentation, despite the principle "let the data circulate instead of the citizens". 
The next most problematic area is outsourcing, which the entrepreneurs found highly burdensome in the area of paying public duties, completing and submitting financial and accounting reports and when (re)establishing an enterprise (Figure 3). To allow enterprises to perform all of their financial and other obligations in the areas of public duties and accounting, they usually must hire external experts since they do not have enough or appropriate resources (e.g. knowledge, staff, time) (cf. Burden et al., 2012). This is expensive, especially for private entrepreneurs. In order to improve this situation, the state should enforce clear rules that are not subject to constant amendment and are easy to apply. Moreover, one-stop shops should be competent to help enterprises when dealing with public duties, accounting etc.

Finally, extra personal communication is assessed as the least burdensome. Not surprisingly, it is evaluated as the most problematic when dealing with inspection procedures, followed by the construction permit procedures and (re)establishing an enterprise (Figure 3). Namely, these special administrative procedures need a certain level of personal contact with the authorities. Although when it comes to establishing a limited liability enterprise or becoming a private entrepreneur, much of the procedure can already be carried out online and at the one-stop shops, this could be improved for the other two areas, i.e. fewer documents, merged procedures, which are at least to some extent available online. With regard to (re)establishing an enterprise it seems the entrepreneurs do not really know of the existence of e-services and, even when they do, they still prefer personal contact. When identifying the nature of the revealed administrative barriers, legal and institutional elements are common to all seven areas. Moreover, some also have a technical component, such as (re)establishing an enterprise, inspection procedures, payment of public duties and dealing with the employees.

It is evident that entrepreneurs need clear sectoral regulation with a minimum burden of extra documents (legal and institutional barriers). This ensures the stability and predictability of the (legal) environment and is consequently attractive to investors. The processes should be performed effectively, i.e. quick, legal, and service-oriented, at low cost (legal and institutional barriers). Namely, what is important for businesses are the ease of hiring and changing personnel, enabling a smooth workflow, the ease of getting construction permits, as well as paying taxes, reporting to the state etc. Finally, all kinds of e-measures when implemented effectively (i.e. with adequate knowledge of all stakeholders involved and constant updates etc.) can profoundly help to ensure the processes are effective (technical barriers).

For these legal, institutional and technical challenges, we need suitable improvements. The challenge is how to synchronize them, since the malfunctioning of one could have a domino effect on the others and ultimately the system's overall ineffectiveness.

\section{Key measures for cutting red tape for SMEs}

Despite the positive effects of legal improvements in Slovenia in the past (e.g. one-stop shops; abolition of income tax returns; a unified working permit for foreigners etc.), the results of the survey show they are only partly satisfactory. In order to improve the system, we need further legal, institutional and technical improvements (see Figure 4). 
Figure 4: Solutions identified for reducing red tape in the selected areas

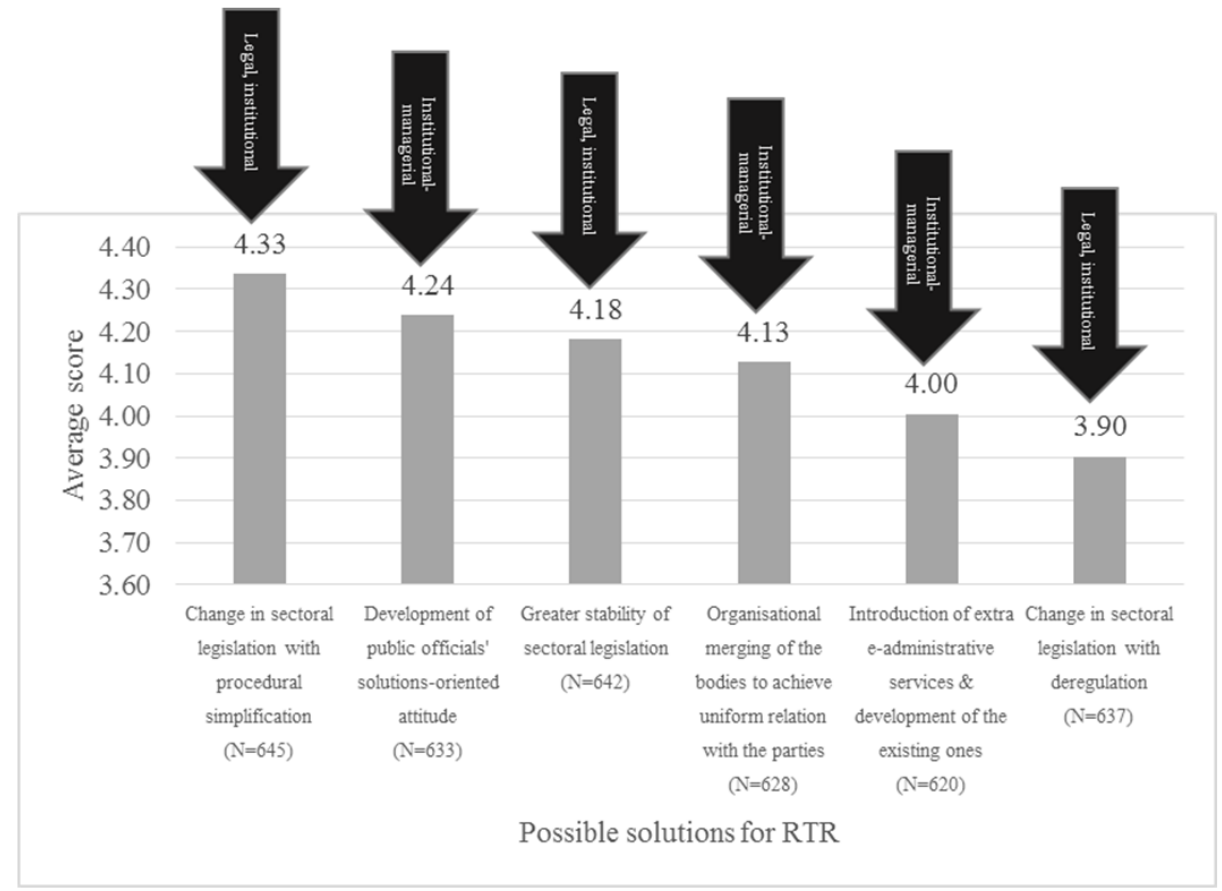

Source: own (2017)

Certain improvements could be made through regulation by way of either simplification or deregulation ("institutional challenge"). Namely, we first need competent bodies to accept smart and stable regulation, and to redefine bodies that are to perform the tasks. Second, competent bodies should effectively implement regulation by focusing on the organizational-managerial part of the changes, with a view to maximizing the processes and workload within the competent units. Moreover, the state should promote solutionsoriented mind-set among officials.

In terms of simplification, measures like merging procedures, introducing more onestop shops, exchanging data between the authorities directly, parties' applications and the serving of documents by ordinary e-mail are suggested. Most of these are already applicable in practice, but there is always space for improvements.

Finally, to provide fundamental support for legal and instrumental problems e-solutions should be introduced and ensured with a "knowledge back up" (of public officials and parties; with relevant updates and development). The state should definitely invest in new technologies, to enable effective services and to follow up the private sector. Although Slovenia has completed a number of successful projects within e-government (one-stop shops, tax bot "Vida", e-land register etc.), there is still a lot of potential for improvement. Figure 4 results partially confirm our third hypothesis. Surprisingly, entrepreneurs find 
as the most important solution to RTR stable regulation coupled with simplification processes. However, e-solutions are only placed in fifth place, even though informatization can actually represent an important part of a simplification process.

Table 4: Spearman's correlation coefficients between solutions for reducing administrative barriers and the perceived extent of administrative barriers in individual areas

\begin{tabular}{|c|c|c|c|c|c|c|}
\hline & $\begin{array}{l}\text { Greater } \\
\text { stability of } \\
\text { sectoral } \\
\text { legislation }\end{array}$ & $\begin{array}{l}\text { Change in } \\
\text { sectoral } \\
\text { legislation } \\
\text { with dere- } \\
\text { gulation }\end{array}$ & $\begin{array}{l}\text { Change in } \\
\text { sectoral } \\
\text { legislation } \\
\text { with } \\
\text { procedural } \\
\text { simplifi- } \\
\text { cation }\end{array}$ & $\begin{array}{l}\text { Introduction } \\
\text { of extra } \\
\text { e-adminis- } \\
\text { trative } \\
\text { services } \\
\& \text { develop- } \\
\text { ment of the } \\
\text { existing } \\
\text { ones }\end{array}$ & $\begin{array}{l}\text { Organiza- } \\
\text { tional } \\
\text { merging of } \\
\text { the bodies } \\
\text { to achieve } \\
\text { uniform } \\
\text { relation } \\
\text { with the } \\
\text { parties }\end{array}$ & $\begin{array}{l}\text { Develop- } \\
\text { ment of } \\
\text { public } \\
\text { officials' } \\
\text { solutions- } \\
\text { oriented } \\
\text { attitude }\end{array}$ \\
\hline $\begin{array}{l}\text { Dealing with } \\
\text { the } \\
\text { employees }\end{array}$ & $\begin{array}{l}0.134 * * \\
(\mathrm{~N}=458)\end{array}$ & $\begin{array}{l}0.151 * * \\
(\mathrm{~N}=455)\end{array}$ & $\begin{array}{c}0.076 \\
(\mathrm{~N}=455)\end{array}$ & $\begin{array}{c}0.015 \\
(\mathrm{~N}=450)\end{array}$ & $\begin{array}{c}0.019 \\
(\mathrm{~N}=450)\end{array}$ & $\begin{array}{c}-0.002 \\
(\mathrm{~N}=451)\end{array}$ \\
\hline $\begin{array}{l}\text { Taxes and } \\
\text { other } \\
\text { contributions }\end{array}$ & $\begin{array}{c}0.051 \\
(\mathrm{~N}=462)\end{array}$ & $\begin{array}{c}0.099 * \\
(\mathrm{~N}=461)\end{array}$ & $\begin{array}{c}0.093 * \\
(\mathrm{~N}=461)\end{array}$ & $\begin{array}{c}0.013 \\
(\mathrm{~N}=451)\end{array}$ & $\begin{array}{c}0.073 \\
(\mathrm{~N}=451)\end{array}$ & $\begin{array}{c}0.059 \\
(\mathrm{~N}=454)\end{array}$ \\
\hline $\begin{array}{l}\text { Accounting } \\
\text { and financial } \\
\text { reports }\end{array}$ & $\begin{array}{c}0.095^{*} \\
(\mathrm{~N}=457)\end{array}$ & $\begin{array}{l}0.123 * * \\
(\mathrm{~N}=456)\end{array}$ & $\begin{array}{l}0.122 * * \\
(\mathrm{~N}=456)\end{array}$ & $\begin{array}{c}0.053 \\
(\mathrm{~N}=448)\end{array}$ & $\begin{array}{c}0.121 * \\
(\mathrm{~N}=449)\end{array}$ & $\begin{array}{c}0.079 \\
(\mathrm{~N}=450)\end{array}$ \\
\hline $\begin{array}{l}\text { Inspection } \\
\text { and control } \\
\text { procedures }\end{array}$ & $\begin{array}{c}0.166 * * * \\
(\mathrm{~N}=444)\end{array}$ & $\begin{array}{l}0.132 * * \\
(\mathrm{~N}=444)\end{array}$ & $\begin{array}{c}0.063 \\
(\mathrm{~N}=444)\end{array}$ & $\begin{array}{c}0.018 \\
(\mathrm{~N}=437)\end{array}$ & $\begin{array}{c}0.059 \\
(\mathrm{~N}=437)\end{array}$ & $\begin{array}{c}0.096^{*} \\
(\mathrm{~N}=439)\end{array}$ \\
\hline $\begin{array}{l}\text { Construction } \\
\text { and similar } \\
\text { permits }\end{array}$ & $\begin{array}{l}0.201 * * * \\
(\mathrm{~N}=407)\end{array}$ & $\begin{array}{c}0.127 * \\
(\mathrm{~N}=407)\end{array}$ & $\begin{array}{c}0.078 \\
(\mathrm{~N}=409)\end{array}$ & $\begin{array}{c}-0.053 \\
(\mathrm{~N}=402)\end{array}$ & $\begin{array}{c}0.078 \\
(\mathrm{~N}=405)\end{array}$ & $\begin{array}{l}0.143 * * \\
(\mathrm{~N}=406)\end{array}$ \\
\hline $\begin{array}{l}\text { (Re)estab- } \\
\text { lishment of } \\
\text { an enterprise }\end{array}$ & $\begin{array}{c}0.116^{*} \\
(\mathrm{~N}=414)\end{array}$ & $\begin{array}{c}0.179 * * * \\
(\mathrm{~N}=412)\end{array}$ & $\begin{array}{c}0.069 \\
(\mathrm{~N}=415)\end{array}$ & $\begin{array}{c}-0.062 \\
(\mathrm{~N}=409)\end{array}$ & $\begin{array}{c}0.044 \\
(\mathrm{~N}=410)\end{array}$ & $\begin{array}{c}0.093 \\
(\mathrm{~N}=411)\end{array}$ \\
\hline
\end{tabular}

Note: $* p<0.05 ; * * p<0.01 ; * * * p<0.001$

Source: own (2017)

The results of Spearman's rank correlation analysis that examined the relationships between solutions for cutting administrative barriers and the perceived extent of administrative barriers in individual areas are presented in Table 4. Although the Spearman rank correlation analysis reveals that all relationships are weak or very weak, the statistical significance of the correlation coefficients suggests which solutions to reducing administrative barriers are more suitable for different administrative areas. The results confirm our fourth hypothesis that the suitability of solutions for the detected administrative 
barriers varies depending on the administrative area involved. The results reveal a positive correlation between greater stability of sectoral legislation and five of the key administrative areas (employees, accounting, inspections, construction permits and (re)establishing an enterprise). This suggests that ensuring the greater stability of sectoral legislation is a suitable solution for these administrative areas, especially for obtaining construction permits due to it holding the highest correlation coefficient value. Change the sectoral legislation with deregulation seems a suitable solution for all key administrative areas, particularly the area of (re)establishing an enterprise. Moreover, changing the sectoral legislation with procedural simplification is suitable for the administrative areas of paying public duties and accounting. Interestingly, the introduction of extra e-services and development of existing ones is not suitable for any of the key administrative areas. The reason for this is that some entrepreneurs are often unfamiliar with the proper application of e-services, which are sometimes perceived as complicated, time-consuming and not user-friendly. Further, the organizational merging of the bodies to achieve uniform relations with the parties is the most suitable solution for the administrative area of accounting. Finally, the development of a solutions-oriented attitude among public officials seems to be the most suitable solution for the areas of inspections and construction permits.

\section{Discussion}

Different stakeholders experience and assess red tape in various ways (cf. Burden et al., 2012). Certain rules might be perceived as burdensome by one organization or an individual in that organization, while others in the same or another organization might assess them as necessary. Moreover, only knowing rules on paper and experiencing them in practice can change stakeholders' perception. Finally, rules that are not perceived as burdensome might have such an effect in reality (Burden et al., 2012).

Therefore, RTR is a continuous activity that should appear in the mind-set of all stakeholders involved, promoting a 'culture of simplification'. Improvement processes should be initiated through the whole cycle, i.e. policymaking, law-making and law enforcement. The goal is to form legitimate public policies. In order to achieve it, different methods should be employed, such as simplification, the consolidation of existing regulation, following up on evaluation recommendations (Cărăuşan, 2016) etc.

An interesting dilemma arising from differences in EU Member States is to enable services of comparable quality. Yet in certain states, the criteria are lower and it is easier to acquire certain rights, permits etc., questioning the principle of equality. Consequently, such environments are of course more attractive to investment (cf. Couyoumdjian, 2012; Jáč and Vondráčková, 2017). Therefore, a good balance between regulation and deregulation as well as simplification should be targeted. Slovenia formed part of the EU program to bring about a $25 \%$ reduction of administrative burdens on business, which encouraged constant monitoring and thus changes. Interestingly, the occurrence of "hyper" regulation (cf. Schulz, 1998) was evident after 2004 when Slovenia joined the EU (e.g. while in 2004 there were approximately 12,000 valid acts, in 2016 there were around 19,000). In this respect, as shown in our survey, there are still many opportunities to improve the current regulation, procedures and overall public services. 
Enterprises in Slovenia mostly encounter administrative barriers when dealing with the state (public administration) in the areas of sectoral regulation, employees, payment of public duties, accounting, inspections, construction permits, and (re)establishing an enterprise. Among these areas, the entrepreneurs identified as the most burdensome the number of the documents needed, the time needed to perform a procedure and the need for outsourcing.

The second part of the survey focused on finding solutions. The entrepreneurs assessed the following as the most favourable: procedural simplification, a solutions-oriented approach among public officials, stability of legislation, organizational efficiency, introduction of more e-services and deregulation.

First, for a more solutions-oriented approach among public officials a shift in mind-set is needed, from public administration to public management. The strict formalistic legal approach should be softened and the costs and benefits of a certain regulation should be taken into account. The solution is not to regulate more, but to find new effective ways of introducing public policies. Second, if the state decides to simplify a procedure or even deregulate certain areas, the accountability of the parties themselves should increase, together with self-regulation controls and inspections (Kovač and Jukić, 2017).

However, certain level of regulation is always needed in order to protect the public interest. The most effective way to increase efficiency in terms of improving the businessfriendly environment is through a synthesis of legal, institutional, managerial and technical measures. When regulating and enforcing the legislation, the principle of proportionality should act a guideline for the authorities. Moreover, extending the scope of discretionary powers is a useful tool for achieving greater flexibility. However, such changes can be dangerous and require qualified public officials who have internalized the highest moral and ethical values. Otherwise, this 'neoliberal shift' from administrate to manage could lead to chaos, corruption, arbitrariness and illegality.

Finally, when transferring good practices from one administrative system to another, we need to take account of the tradition, constitutional order, size of a country etc. Therefore, not every institute or practice which works in one country will also be good in another. As seen in our survey, the entrepreneurs think there are more administrative barriers in Slovenia than in other countries. For example, Austria was often regarded as a role model. Therefore, in the future it would be interesting to broaden our research to cover other EU countries and check the perception of foreign SMEs with respect to their public administration (state) performance. After all, all EU Member States are required to respect the same EU legislation, but the question arises how they implement it in practice to remain competitive. 


\section{Conclusion}

Extensive legislation containing unclear rules that demand much work be done on the entrepreneur's side (i.e. requiring them to know all the rules and collect all the data and documents; to know the e-system etc.) prolongs procedures and leads to extensive documentation and even outsourcing.

In order to improve the business environment, RTR should be one of the state's guidelines and goals when regulating different areas of society. Beside the removal of administrative barriers, it demands respect of the accountability and transparency of the Government. However, legal rules should be seen as a vehicle for ensuring that procedures are efficient. The state can achieve this by applying different methods throughout the policy- and law-making cycle, such as regulatory impact assessment, simplification, deregulation, e-government etc.

Around the world, values such as time, costs and final profit determine how successful enterprises become. Therefore, the state should encourage those legal and institutional measures, supported by E-Systems, that make doing business overall effective. Although Slovenia is a micro system, it has formed part of the larger European administrative space since 2004. Therefore, the setting up of the administrative areas and the identified administrative barriers that entrepreneurs might encounter as well as their assessment of possible solutions provide an important baseline for another future comparative research, especially among the EU.

\section{Acknowledgement}

The authors acknowledge the project Public Administration performance and procedural (de)bureaucratization in the context of SME development: a comparative analysis of Slovenia and Croatia (BI-HR/16-17-009) was financially supported by the Slovenian Research Agency.

\section{References}

Aristovnik, A. and Obadić, A. (2015). The impact and efficiency of public administration excellence on fostering SMEs in EU countries. Amfiteatru economic, 17(39), 761-774.

Bozeman, B. (1993). A Theory of Government 'Red Tape'. Journal of Public Administration Research and Theory, 3(3), 273-303.

Braunerhjelm, P. and Eklund, J. E. (2014). Taxes, tax administrative burdens and new firm formation. Kyklos, 67(1), 1-11.

Burden, B. C., Canon, D. T., Mayer, K. R. and Moynihan, D. P. (2012). The Effect of Administrative Burden on Bureaucratic Perception of Policies: Evidence from Election Administration. Public Administration Review, 72(5), 741-751, doi: 10.1111/j.15406210.2012.02600.x.

Cărăuşan, M. (2016). Better Regulation a Renewed Impetus of the European Union. Journal of Public Administration, Finance and Law, 8, 114-121.

Companies Act. Official Gazette of the Republic of Slovenia 42/06, 65/09 - official consolidated text, 33/11, 91/11, 32/12, 57/12, 44/13 - odl. US, 82/13, 55/15, and 15/17. 
Couyoumdjian, J. B. (2012). Who walks out? Entrepreneurship in a global economy. International Review of Law and Economics, 32(1), 158-165, doi:10.1016/j.irle.2011.12.001. Donelan, E. (2008). Administrative simplification, an overarching policy to maintain a balance between the protection of the public interest and interests of businesses. SIGMA, 8-9 May 2008, Ankara.

Đorðević, M. (2017). Zadržan odnos do lestvice držav Doing Business [Reserved Attitude towards Doing Business Scale], Pravna praksa, 36(20/21), 19-23.

European Commission (2003). Commission Recommendation concerning the definition of micro, small and medium-sized enterprises (Text with EEA relevance) (notified under document number C(2003) 1422) Official Journal L 124, 20. 5. 2003.

European Commission (2007). Models to reduce the disproportionate regulatory burden on SMEs, Report of the Expert Group, Brussels: European Commission.

European Commission (2017). 2016 SBA Fact Sheet, Ref. Ares (2017)1735504 31/03/2017, 2017.

Hauke, J. and Kossowski, T. (2011). Comparison of values of Pearson's and Spearman's correlation coefficients on the same sets of data. Quaestiones geographicae, 30(2), 87-93, doi: https://doi.org/10.2478/v10117-011-0021-1.

International SCM Network to reduce administrative burdens (2005). International Standard Cost Model Manual.

Jáč, I. and Vondráčková, M. (2017). The Perception of Selected Aspects of Investment Attractiveness by Businesses Making Investments in the Czech Republic. E\&M Ekonomika a Management, 20(3), 118-132, doi: 0.15240/tul/001/2017-3-008.

Kaufman, W. and Feeney, M. K. (2012). Objective Formalization, Perceived Formalization and Perceived Red Tape. Public Management Review, 14(8), 1195-1214, http://dx.doi.org/10.1080/14719037.2012.662447.

Kaufmann, W. and Feeney, M. K. (2014). Beyond the Rules: The Effect of Outcome Favourability on Red Tape Perceptions. Public Administration, 92(1), 178-191, doi: 10.1111/padm.12049.

Kovač, P. (2018). Potentials of administrative procedures as a participatory tool within governance models in Central and Eastern Europe. Danube: law and economics review, 9(4), 227-244.

Kovač, P. and Jukić, T. (2017). Recent Regional Developments in Red Tape Reduction - a Content Analysis of Web of Science Journals. Lex localis, 15(3), 433-457, doi: 10.4335/15.3.433-457 (2017).

Kovač, P. and Sever, T. (2016). Sistemski vidiki razumevanja koncepta odprave administrativnih ovir [Systemic Aspects of Understanding the Concept of Red Tape Reduction]. In Dečman, M. (ed.). Učinkovitost storitev + demokratičnost oblasti $=$ dobro upravljanje? [Efficiency of Services + Democracy of Authority = Good Governance?]. Ljubljana: Faculty of Administration.

Obadić, A., Ravšelj, D. and Aristovnik, A. (2020). Administrative Barriers in the Field of Employment in the EU: Empirical Evidence from Croatia and Slovenia. International Journal of Economics \& Business Administration (IJEBA), 8(2), 533-553. 
OECD (2003). From Red Tape to Smart Tape: Administrative Simplification in OECD Countries, OECD.

OECD (2008). Forum on Tax Administration: Taxpayers Services Sub-group. Programs to Reduce Administrative Burden of Tax Regulations in Selected Countries, 2008, [Online] at https://www.oecd.org/ctp/administration/39947998.pdf, accessed December 20, 2019.

Pandey, S. K., Coursey, D. H. and Moynihan, D. P. (2007). Organizational Effectiveness and Bureaucratic Red Tape: A Multimethod Study. Public Performance and Management Review, 30(3), 398-425.

Pandey, S. K. and Scott, P. G. (2002). Red Tape: A Review and Assessment of Concepts and Measures. Journal of Public Administration Research and Theory, 12(4), 553-580, https://doi.org/10.1093/oxfordjournals.jpart.a003547.

Radaelli, C.M. and De Francesco, F. (Eds.) (2007). Regulatory Quality in Europe Concepts, Measures and Policy Processes. Manchester, New York: Manchester University Press.

Ravšelj, D. and Aristovnik, A. (2020). The Relationship between Tax-Related Administrative Barriers and SMEs Characteristics: Evidence from Slovenia. European Research Studies Journal, 23(1), 381-388.

Ravšelj, D., Kovač, P., \& Aristovnik, A. (2019). Tax-Related Burden on SMEs in the European Union: The Case of Slovenia. Mediterranean Journal of Social Sciences, 10(2), 69-79.

Rosenfeld, R. A. (1984). An Expansion and Application of Kaufman's Model of Red Tape: The Case of Community Development Block Grants. The Western Political Quarterly, 37(4), 603-620.

Schulz, M. (1998). Limits to Bureaucratic Growth: The Density Dependence of Organizational Rule Births. Administrative Science Quarterly, 43(4), 845-876.

Statistical Office RS (2017). SiStat Database. Ljubljana: Statistical Office RS. Retrieved September 22, 2020, from https://pxweb.stat.si/SiStat/en.

Szczepański, M. (European Parliament) (2016). Barriers to SME growth in Europe, Briefing.

The World Bank (2016, 2017, 2020). Doing Business. Retrieved September 23, 2020, from https://www.doingbusiness.org/en/data/exploreeconomies/slovenia.

Virant, G. and Kovač, P. (2010). Reducing administrative burdens as part of the "better regulation" programme - The case of Slovenia. Lex localis, 8(4), 369-390, doi: 10.4335/8.4.369-390 (2010). 